\title{
Liver transplantation in HIV-1-infected patients
}

José M Miró

\author{
From $16^{\text {th }}$ International Symposium on HIV and Emerging Infectious Diseases \\ Marseille, France. 24-26 March 2010
}

With the advent of highly active antiretroviral therapy in 1996, patients infected with HIV are now living longer and dying from illnesses other than acquired immunodeficiency syndrome (AIDS). Liver disease due to chronic hepatitis $B$ and $C$ is now a leading cause of mortality among HIV-infected patients in the developed world. For these patients, liver transplantation (OLT) is the only therapeutic option and HIV infection alone is not a contraindication. The current HIV selection criteria for HIV-infected OLT candidates are as follows: 1) ideally no history of opportunistic infections or HIVrelated cancer, although some treatable and preventable opportunistic infections are not exclusion criteria; 2 ) CD4 cell count $>100$ cells $/ \mathrm{mm}^{3}$; and, 3) plasma HIV RNA viral load that is undetectable or can be suppressed with antiretroviral treatment. Drug users must abstain from heroin and cocaine, although patients can be in a methadone programme. Accumulated experience in North America and Europe in the last few years indicates that five-year survival in liver recipients coinfected with HIV and HCV is lower than that of HCV-monoinfected recipients, being the five-year survival of around $50 \%$. Conversely, 3-5-year survival of non-HCV-HIVcoinfected liver recipients is very good and it was similar to that of HIV-negative patients. Pharmacokinetic (PK) and pharmacodynamic interactions between NNRTI- or protease-inhibitor based regimens and immunosuppressors have been one of the most important problems in the post-trasplant period, although with the new NNRTI- and protease inhibitor-sparing raltegravir-based regimens we can avoid them. Other problems in the post-transplant period are the high rates of acute rejection, and the HCV re-infection in HIV-infected liver recipients, that is the main cause of mortality. Better

Infectious Diseases Service, Hospital Clinic - IDIBAPS, University of Barcelona, Barcelona, Spain

B̈̈oMed Central @ 2010 Miró; licensee BioMed Central Ltd.
anti-HCV management and therapy could improve the long-term outcome of OLT recipients coinfected with $\mathrm{HIV}$ and $\mathrm{HCV}$.

Published: 11 May 2010

doi:10.1186/1742-4690-7-S1-125

Cite this article as: Miró: Liver transplantation in HIV-1-infected patients. Retrovirology 2010 7(Suppl 1):125.
Submit your next manuscript to BioMed Central and take full advantage of:

- Convenient online submission

- Thorough peer review

- No space constraints or color figure charges

- Immediate publication on acceptance

- Inclusion in PubMed, CAS, Scopus and Google Scholar

- Research which is freely available for redistribution

Submit your manuscript at www.biomedcentral.com/submit
C Biomed Central 